\title{
PENGARUH CAPITAL ASSET DAN NON-CAPITAL ASSET TERHADAP TINGKAT PENDAPATAN NELAYAN DI DESA SALAJANGKI, KABUPATEN GOWA
}

\author{
Sukrin $^{1}$ \\ Andi Faisal Anwat ${ }^{2}$
}

\begin{abstract}
ABSTRAK
Dusun Pamandongan Desa Salajangki merupakan satu-satunya Desa yang memiliki pesisir pantai yang ada di Kabupaten Gowa. Permasalahan yang di hadapi nelayan di Dusun Pamandongan ini yaitu pendapatan nelayan yang rendah dan tidak menentu. Penelitian ini bertujuan untuk menjelaskan pengaruh capital asset yakni modal, pengalaman, teknologi dan factor non-capital asset seperti jumlah tanggungan dan jarak tempuh terhadap tingkat pendapatan nelayan. Hasil analisis menunjukan bahwa variabel capital asset maupun noncapital asset yakni modal, pengalaman, teknologi, jumlah tanggungan dan jarak tempuh secara simultan berpengaruh positif dan signifikan terhadap pendapatan nelayan, sedangkan secara parsial bahwa variabel modal pengalaman, teknologi, dan jarak tempuh berpengaruh positif dan signifikan terhadap pendapatan nelayan. Variable jumlah tanggungan, nampaknya berpengaruh positif tetapi tidak signifikan terhadap pendapatan nelayan.
\end{abstract}

Kata kunci: Pendapatan Nelayan, Modal, Pengalaman, Teknologi, Jumlah Tanggungan, Jarak Tempuh.

\section{PENDAHULUAN}

Nelayan di Desa Salajangki, Kecamatan Bontonompo Selatan menyandarkan hidupnya pada aktifitas melaut semata. Namun mereka di perhadapkan dengan berbagai macam masalah, salah satunya adalah cuaca yang tidak menentu, sehingga tingkat pendapatannya pun juga tidak menentu. Kondisi ekstrim ini, di perparah dengan keterbatasan capital asset maupun non capital asset yakni modal untuk melaut, skill yang rendah dengan rata-rata lama sekolah hanya tamat SD, jumlah tanggungan yang banyak dalam keluarga, keterbatasan alat tangkap (teknologi) dan kepemilikan kapal yang sangat sederhana, sehingga hasil tangkapan yang di peroleh sangat sedikit. Dengan kondisi rentan seperti ini, berdampak besar terhadap pendapatan nelayan yang

1 STAIN Curup Bengkulu, alexlesti@gmail.com

2 STAIN Curup Bengkulu, rizallempur@gmail.com 
ada di Desa Salajangki. Dengan kata lain, nelayan di perhadapkan dengan berbagai keterbatasan. Di saat yang sama, mereka harus memenuhi kebutuhan hidupnya, yang dari waktu ke waktu semakin meningkat. Hal ini sangat berpengaruh terhadap pendapatan nelayan yang ada di daerah ini. Berdasarkan masalah tersebut, menarik untuk diketahui seberapa besar pengaruh capital asset maupun non capital asset seperti modal, pengalaman, teknologi, jumlah tanggungan dan jarak tempuh terhadap tingkat pendapatan nelayan.

\section{TINJAUAN PUSTAKA}

Gregory Mankiw (2007) mengemukakan bahwa modal merupakan capital asset seperti barang maupun uang yang secara bersama-sama digunakan sebagai faktor produksi, tanah dan tenaga kerja untuk menghasilkan barang yang baru. Peranan modal begitu esensial untuk meningkatkan produktivitas, dengan bertambahnya keterampilan dan kecakapan pekerja, pada akhirnya akan menaikkan produktivitas produksi itu sendiri.

Pandangan Sadono Sukirno (2002) menerangkan bahwa pengalaman kerja yaitu sebuah proses pembentukan sebuah pengetahuan atau keterampilan seseorang tentang metode, suatu pekerjaan yang mampu meningkatkan tingkat produktivitas. Pengalaman juga dapat dikategorikan sebagai capital asset yang berbentuk human capital yakni pengalaman atau skill.

Menurut Gregory Mankiw (2007) bahwa kemajuan teknologi memberikan kemudahan kepada efesiensi tenaga kerja. Penggunaan akan teknologi, memberikan kemudahan kepada nelayan dalam beroperasi. Namun, berbeda dengan Solow dan David Ricardo, yang memberikan gambaran bahwa pertumbuhan yang berkelanjutan dalam pendapatan, berasal dari kemajuan teknologi, yang dapat membantu proses dan akan meningkatkan produktivitas tenaga kerja. Dalam hal ini teknologi juga dapat dikategorikan sebagai physical capital asset yang dapat menambah produktivitas produksi.

Menurut Nuratul Awalia (2016) menegaskan bahwa tanggungan keluarga yaitu semua anggota yang langsung menjadi beban tanggungan dari nelayan. Tanggungan keluarga yang besar, merupakan faktor dominan, yang akan mempengaruhi pengeluaran rumah tangga. Semakin kecil jumlah tanggungan dalam sebuah rumah tangga akan mempengaruhi rendahnya jumlah 
pengeluaran. Prinsipnya, faktor jumlah tanggungan, dimaknai sebagai pengeluaran yang dapat mengurangi jumlah pendapatan, serta tidak dapat dikategorikan sebagai capital asset, justru merupakan antitesa dari capital asset itu sendiri .

Menurut (Rokhmin Dahuri, 2004) menggambarkan bahwa faktor jarak tempuh yang dilalui nelayan ketika melaut, merupakan salah satu faktor yang mempengaruhi tingkat pendapatan, apabila jarak tempuh semakin jauh, maka hasil produksi nelayan akan semakin meningkat, sehingga memberikan pendapatan yang lebih besar kepada nelayan, dibandingkan penangkapan yang dilakukan didekat pantai.

Menurut (Robinson, 2005) berpandangan bahwa tujuan utama dalam melakukan perdagangan yaitu untuk memperoleh pendapatan, pendapatan diperoleh dari kegiatan yang dilakukan, untuk mendapatkan keuntungan. Keuntungan ditentukan dengan cara mengurangkan biaya tetap, misalnya (biaya penyusutan perahu, biaya penyusutan mesin dan biaya penyusutan alat tangkap) dan biaya variabel seperti (bahan bakar minyak dan es balok) yang dikeluarkan selama proses kerja. Proses akumulasi keuntungan tersebut, pada akhirnya akan mengakumulasi capital asset itu sendiri. Semakin tinggi capital asset yang dimiliki seseorang, maka tingkat kesejahteraannya pun akan semakin tinggi.

\section{METODE PENELITIAN}

Jenis metode penelitian yang digunakan dalam penelitian ini adalah metode deskriptif kuantitatif, data yang diperoleh dari sampel populasi penelitian, dianalisis sesuai dengan metode statistik dan kemudian diinterpretasikan. Lokasi penelitian ini bertempat di Dusun Pamandongan, Desa Salajangki, Kecamatan Bontonompo Selatan, Kabupaten Gowa. Data primer secara khusus dikumpulkan oleh peneliti untuk menjawab pertanyaan penelitian. Dalam penelitian ini, data diambil berdasarkan interview yang diwawancarakan kepada responden. Sementara data sekunder dalam penelitian ini diperoleh dari BPS maupun instansi terkait seperti Kantor Desa Salajangki, Kecamatan Bontonompo Selatan, Kabupaten Gowa.

Peneliti menggunakan teori produksi Cobb-Douglas sebagai referensi dalam menentukan fungsi produksi. Fungsi Cobb-Douglas adalah suatu fungsi atau persamaan yang melibatkan dua atau lebih variabel, dimana variabel 
pertama disebut dengan variabel dependen (yang dijelaskan/Y), dan yang lain disebut variabel independen (yang menjelaskan/X).

Untuk estimasi koefisien regresi, ditransformasi ke bentuk linear, guna menghitung nilai elastisitas dari masing-masing variabel bebas terhadap variabel terikat, ke dalam model sehingga diperoleh persamaan sebagai berikut:

$$
Y=\beta 0+\beta 1 X 1+\beta 2 X 2+\beta 3 X 3+\mu
$$

Pengujian hipotesis dalam penelitian ini, meliputi pengujian uji asumsi klasik yang meliputi multikolinearitas, heteroskedasitas, autokorelasi dan normalitas, uji koefisien determinan (R2), uji simultan (uji f), uji parsial (uji t).

\section{HASIL DAN PEMBAHASAN}

Berdasarkan penelitian yang dilakukan terhadap 65 responden, di Dusun Pamandongan, Desa Salajangki yang dianalisis secara regresi dan uji statistik, untuk membuktikan hipotesis yang diteliti. Variabel yang diteliti adalah modal, pengalaman, teknologi, jumlah tanggungan dan jarak tempuh terhadap pendapatan nelayan.

\section{Pengaruh Modal Kerja Terhadap Pendapatan Nelayan}

Berdasarkan hasil uji $\mathrm{t}$ diperoleh keterangan bahwa variabel modal berhubungan positif dan signifikan terhadap pendapatan nelayan. Variabel modal kerja $\left(X_{1}\right)$ menunjukkan nilai signifikan $<\alpha(0.000<0.05)$ dengan nilai $\beta_{1}$ sebesar 0.300 , artinya jika variabel pengalaman, teknologi, jumlah tanggungan dan jarak tempuh konstan. Dan variabel modal kerja mengalami kenaikan sebesar $1 \%$ maka pendapatan nelayan mengalami peningkatan sebesar 0.300 .

Berdasarkan hasil analisis yang diperoleh, dapat dijelaskan bahwa variabel modal berpengaruh positif terhadap terhadap pendapatan nelayan. Hal ini berarti penambahan modal akan berdampak pada peningkatan pendapatan nelayan.

\section{Pengaruh Pengalaman Terhadap Pendapatan Nelayan}

Berdasarkan hasil uji t diperoleh keterangan bahwa variabel pengalaman berhubungan positif dan signifikan terhadap pendapatan nelayan, variabel pengalaman $\left(X_{2}\right)$ menunjukkan nilai signifikan $<\alpha(0.001<0.05)$ dengan nilai $\beta_{2}$ sebesar 0.136 , Artinya jika variabel modal kerja, teknologi, jumlah tanggungan dan jarak tempuh konstan. Variable pengalaman mengalami kenaikan sebesar $1 \%$ 
maka pendapatan nelayan mengalami peningkatan sebesar 0.136 . Koefisien bernilai positif, artinya terjadi hubungan positif antara pengalaman dan pendapatan. Dengan demikian, semakin tinggi tingkat pengalaman akan berdampak pada peningkatan pendapatan nelayan.

\section{Pengaruh Teknologi Terhadap Pendapatan Nelayan}

Berdasarkan hasil uji t diperoleh keterangan bahwa variabel teknologi berhubungan positif dan signifikan terhadap pendapatan nelayan variabel teknologi $\left(X_{3}\right)$ menunjukkan nilai signifikan $<\alpha(0.000<0.05)$ dengan nilai $\beta_{3}$ sebesar 0.536 , Artinya jika variabel modal kerja, pengalaman, jumlah tanggungan dan jarak tempuh konstan. Ketika variabel teknologi mengalami kenaikan sebesar $1 \%$, maka pendapatan nelayan mengalami peningkatan sebesar 0.536 . Dengan kata lain, terjadi hubungan positif antara teknologi dan pendapatan. Hal ini berarti meningkatnya teknologi yang di gunakan akan berdampak pada peningkatan pendapatan nelayan.

\section{Pengaruh jumlah tanggungan Terhadap Pendapatan Nelayan}

Berdasarkan hasil uji $\mathrm{t}$ diperoleh keterangan bahwa variabel jumlah tanggungan berhubungan positif dan tidak sgnifikan terhadap pendapatan nelayan variabel jumlah tanggungan $\left(X_{4}\right)$ menunjukkan nilai signifikan $>\alpha(0.107>0.05)$ dengan nilai $\beta_{4}$ sebesar 0.024 , Artinya jika variabel modal kerja, pengalaman, teknologi dan jarak tempuh konstan. Variabel jumlah tanggungan mengalami kenaikan sebesar $1 \%$, maka pendapatan nelayan mengalami peningkatan sebesar 0.024. Terjadi hubungan positif antara jumlah tanggungan dan pendapatan. Berdasarkan hasil analisis yang diperoleh, dapat dijelaskan bahwa variabel jumlah tanggungan berpengaruh positif terhadap terhadap pendapatan nelayan, akan tetapi tidak signifikan. Hal ini berarti jumlah tanggungan kurang berpengaruh terhadap pendapatan nelayan.

\section{Pengaruh Jarak Tempuh Terhadap Pendapatan Nelayan}

Berdasarkan hasil uji t diperoleh keterangan bahwa variabel jarak tempuh berhubungan positif dan signifikan terhadap pendapatan nelayan variabel jarak tempuh $\left(X_{5}\right)$ menunjukkan nilai signifikan $<\alpha(0.001<0.05)$ dengan nilai $\beta_{5}$ sebesar 0.079. Artinya jika variabel modal kerja, pengalaman, teknologi dan jumlah 
tanggungan konstan. Variabel jarak tempuh mengalami kenaikan sebesar $1 \%$ maka pendapatan nelayan mengalami peningkatan sebesar 0.079. Dengan demikian, terjadi hubungan positif antara jarak tempuh dan pendapatan. Artinya, semakin jauh jarak tempuh nelayan, maka tingkat pendapatan semakin meningkat.

\section{KESIMPULAN}

Berdasarkan analisis data yang dilakukan dan pembahasan yang telah dikemukakan, maka diperoleh kesimpulan sebagai berikut:

1. Variabel capital asset maupun non capital asset seperti modal, pengalaman, teknologi, jumlah tanggungan dan jarak tempuh, secara simultan berpengaruh signifikan terhadap pendapatan nelayan, sedangkan variabel jumlah tanggungan secara parsial tidak berpengaruh signifikan, namun berhubungan positif terhadap pendapatan nelayan.

2. Variabel capital asset yakni teknologi merupakan variabel yang paling berpengaruh terhadap tingkat pendapatan nelayan.

\section{DAFTAR PUSTAKA}

Awalia, Nuratul. 2016. Pengaruh Modal Kerja, Pengalaman, Teknologi, Jarak Tempuh Dan Pendidikan Terhadap Tingkat Pendapatan Nelayan Di Desa Aeng Batu-Batu Kecamatan Galesong Utara Kabupaten Takalar. (Skripsi tahun 2016).

Dahuri, Rokhmin. 2014. Membangun Kelautan dan Perikanan Jakarta: Pradnya Paramita.

Mankiw, Gregory. 2007. Makro Ekonomi Jakarta:Penerbit Erlangga.

Sukirno, Sadono. 2002. Pengantar Teori Mikroekonomi Jakarta: PT Raja Grafindo Persada.

Tarigan, Robinson. 2005. Ekonomi Regional dalam Teori dan Aplikasi Jakarta: Bumi Aksara. 